\title{
Personal Creativity Effect On Business Performance With Entrepreneurial Orientation As Intervening Variables In Embroidery Industry Enterprises In Aceh
}

\author{
Yuli Kusdiarni \\ A Student of Doctorate Program, \\ Development Extention/Community Empowerment Study Program, \\ Sebelas Maret University \\ Darsono \\ Development Extention/Community Empowerment Study Program, \\ Sebelas Maret University \\ Sapja Anantanyu \\ Development Extention/Community Empowerment Study Program, \\ Sebelas Maret University \\ Mohd. Harisudin \\ Development Extention/Community Empowerment Study Program, \\ Sebelas Maret University
}

\begin{abstract}
Personal creativity, business performance and entrepreneurial orientation are the most important parts for entrepreneurs in running their businesses. This study discusses the influence of personal creativity on business performance withmediation by entrepreneurial orientation. The purpose of this study is: first, to analyze the influence of personal creativity that is significant on entrepreneurial orientation; and second, to analyze the influence of personal creativity and entrepreneurial orientation which are partially and simultaneously significant towards business performance. The method used is distributing questionnaires to 200 embroidery industry entrepreneurs in Aceh as samples. The data analysis tool used is path analysis with SPSS version 22. The results of the analysis show that entrepreneurial orientation is a mediating variable between personal creativity and business performance.
\end{abstract}

Keywords: personal creativity, business performance, entrepreneurial orientation, intervening variable, embroidery industry

\section{INTRODUCTION}

Products with a touch of embroidery have their own added value and appeal. Similarly, the Aceh motif embroidery has its own characteristics that are very special, and is a culture that persists consistently. The influence of certain motives will make embroidery different for each region in Aceh. Even though many similar Acehnese motif embroidery entrepreneurs with tight competition, this industry has its own uniqueness and has high economic value so the integrated embroidery development in potential areas needs to be carried out.

Indirectly this Acehnese motif embroidery has been able to become an ambassador for Acehnese culture. This is none other because of the love and concern of the community in 
utilizing cultural objects by making them various types and styles that are applied to many craft products. The use of Acehnese motif embroidery is very dependent on the creativity of embroidery entrepreneurs in designing patterns and modifying various motifs into a product. In addition, the placement of the technique of matching yarn to cloth or medium to be embroidered must be dominated by finesse and hand skills. Not infrequently also consumers who determine this motive by combining it with various colors according to their wishes.

\section{LITERATURE REVIEW}

\section{Business Performance}

Performance is a concept that is widely used in many areas that shows how well the process of achieving its objectives. According to Glancey (1998) and Wiklund and Shepherd (2003), performance is the result of management activities in managing and developing organizational resources. Performance is as a result of the work that has been achieved by small and medium enterprises to develop their organizations (Wiklund, 1999). According to Armstrong (2004), performance is the result of work that has a strong relationship with the organization's strategic goals, customer satisfaction, and contributing to the economy. Thus performance is about doing the work and the results achieved from the work, which is about what is done and how to do it.

Jauch and Glueck (1988) states that the performance of a business can be seen from the level of sales, the level of profit, return on capital, the turnover rate and market share achieved. The business performance in this research is the results obtained from carrying out activities to make Acehnese motif embroidery. So that business performance is seen from: 1) sales volume; 2) market share; 3) business network; and 4) customers.

\section{Entrepreneurial Orientation}

Miller (1983) provides an operational concept of entrepreneurial orientation as an orientation to try to be the first in product innovation in the market, dare to take risks and take proactive actions to defeat competitors. Companies that use the entrepreneurial approach to strategy making are unique companies when compared to other companies. In line with the opinion of Zahra (1993) that entrepreneurial orientation can be measured from three dimensions, namely proactive-ness, risk taking, and innovativeness. Zahra and Neubaum (1998) state that "Entrepreneurial Orientation is the total number of radical company innovations, proactive strategic actions, and risk-taking activities that are manifested in their support for projects with uncertain results".

Entrepreneurial orientation according to Lumpkin and Dess (1996) is a process, practice, and decision making that causes newcomers to arise (for example by entering new markets or old markets or launching new products). The dimensions that determine the characteristics of entrepreneurial orientation are: autonomy, innovation, willingness to take risks, proactive and aggressive competition. Meanwhile, Messeghem (2003) mentions entrepreneurial orientation is the company"s ability to see new business opportunities. In this case, Messeghem mentions five indicators in looking at entrepreneurial orientation namely standardization, formalization, specialization, planning and control systems, and external information systems. The higher the indicator shows the stronger the entrepreneurial orientation of the leadership of a company. In this study, entrepreneurial orientation is seen from: autonomy, innovation, willingness to take risks, proactive and aggressive competition.

\section{Personal Creativity}

According to Harris (1998) in Okpara (2007) and Gurteen (1998) in Suryana (2013), creativity is characterized by the ability to generate ideas, transform ideas into actions through selection, 
to create into new forms, produce through imaginative skills, and make to bring into existence something new. Creativity is not the ability to create from nothing (because only God can do that), but the ability to produce new ideas by combining, changing, or applying existing ideas. In line with the statement of Zimmerer and Scarborough (2005) that creativity is: the ability to develop new ideas and to find new ways to solve problems in the face of opportunities. In other words, an entrepreneur will succeed by thinking and working on new things or old things in new ways.

While Amabile (1998) and Robbins and Judge (2008) state that, individual creativity are basically requires skills, creative thinking and intrinsic task motivation. The higher each component, the higher the creativity. In this study personal creativity is seen from: skills, creative thinking, intrinsic motivation and extrinsic motivation.

\section{Personal Creativity, Entrepreneurial Orientation, and Business Performance}

In this study, the influence of personal creativity on business performance is seen through entrepreneurial orientation as an intervening variable. Besides that, it is also seen whether there is a direct influence of personal creativity on business performance.

\section{RESEARCH METHOD}

The sample of this study is 200 respondents who have small and medium scale embroidery businesses which are entrepreneurs in the embroidery industry in 7 districts/cities in Aceh, namely: Banda Aceh, Aceh Besar, Bireuen, Aceh Utara, Lhokseumawe, Aceh Tengah and Aceh Tenggara. The method of data collection was taken through questionnaires. The data is then processed using path analysis with the SPSS version 22 program.

\section{Model Testing}

\section{RESULTS AND DISCUSSION}

The classic regression assumption test states that the regression model: 1 ) is free of multi-colinearity because it has a Tolerance value greater than 0.1 (entrepreneurial orientation 0.923 and creativity 0.923) and the VIF value is smaller than 10 (entrepreneurial orientation 1,084 and creativity 1,084); 2) heteroscedasticity does not occur (because data points spread above and below 0 (zero) on the $\mathrm{Y}$ and $\mathrm{X}$ axes and do not form certain patterns such as zigzags and stacking; 3) have a normal distribution because in the histogram image shows a line curving upwards like forming a mountain and looking perfect with symmetrical legs. In addition, the Kolmogorov-Smirnov test calculated Absolute D value of 0.075 that is smaller than the statistical table of 0.096 so that the data follows a normal distribution. The classic regression test results show that the linear regression model can be called a good model.

\section{Output Analysis}

In this section, the results of testing the hypotheses stated in this study are displayed with the help of a statistical software package known as SPSS version 22. For the first path analysis the following results are obtained:

Table 1. Variables Entered/Removed Variables Entered/Removeda

\begin{tabular}{|l|l|l|l|}
\hline Model & Variables Entered & Variables Removed & Method \\
\hline 1 & CREA $^{\text {b }}$ &. & Enter \\
\hline
\end{tabular}

a. Dependent Variable: EO

b. All requested variables entered. 
Table 2. Model Summary

Model Summary

\begin{tabular}{|l|c|r|r|r|}
\hline Model & $\mathrm{R}$ & R Square & $\begin{array}{c}\text { Adjusted R } \\
\text { Square }\end{array}$ & $\begin{array}{c}\text { Std. Error of } \\
\text { the Estimate }\end{array}$ \\
\hline 1 &, $278^{\mathrm{a}}$ &, 077 &, 073 & 7,827860 \\
\hline
\end{tabular}

a. Predictors: (Constant), CREA

Table 3. Anova

ANOVAa

\begin{tabular}{|ll|c|c|c|c|c|}
\hline Model & & Sum of Squares & df & Mean Square & F & Sig. \\
\hline 1 & Regression & 1018,903 & 1 & 1018,903 & 16,628 &, $000^{\mathrm{b}}$ \\
& Residual & 12132,528 & 198 & 61,275 & & \\
& Total & 13151,432 & 199 & & & \\
\hline
\end{tabular}

a. Dependent Variable: E0

b. Predictors: (Constant), CREA

Table 4. Coefficients

Coefficients ${ }^{\mathrm{a}}$

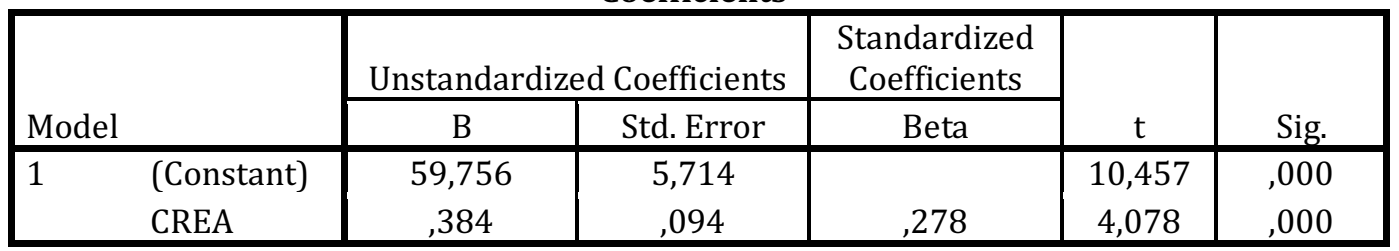

a. Dependent Variable: ORKE

1. Table 1. "Variables Entered/Removed" shows the variable personal creativity as an independent variable and entrepreneurial orientation as the dependent variable.

2. Table 2. "model summary" displays the value of $\mathrm{R}$ which is a symbol of the value of the correlation coefficient. The value of the correlation obtained is 0.278 and interpreted that the relationship between the two research variables is in the weak category. In this table also obtained the value of R Square or coefficient of determination (CD) of $7.7 \%$. This value shows how good the regression model is formed by the interaction of independent variables and dependent variables. Thus it can be interpreted that the variable personal creativity has an influence of $7.7 \%$ contribution to the entrepreneurial orientation variable and the other $92.3 \%$ is influenced by other factors outside the personal creativity variable. The path coefficient value $(€ 1)$ for other variables outside the research are:

$$
\epsilon=\sqrt{1-R^{2}}=\sqrt{1-0,077}=0,961
$$

3. Table 3. "anova" is used to determine the significance level of regression. From the calculation results, the F number of the research is 16,628 , and $p$ count is 0,000 . Decisions of regression models are feasible and can be used to predict entrepreneurial orientation of embroidery industry entrepreneurs. This means that there is a linear relationship between personal creativity and entrepreneurial orientation.

4. Table 4. shows the relationship between personal creativity towards entrepreneurial orientation. Based on the results of the calculation, the research t number is 4.078, which means that there is a linear relationship between personal creativity and entrepreneurial orientation.

5. Thus, the model for the first path is:

$$
Y_{1}=0,961+0,278 X
$$

or:

Entrepreneurial orientation $=0,961+0,278$ Personal Creativity 
For the second path analysis, the following results are obtained:

Table 5. Variables Entered/Removed Variables Entered/Removeda

\begin{tabular}{|l|l|l|l|}
\hline Model & $\begin{array}{c}\text { Variables } \\
\text { Entered }\end{array}$ & $\begin{array}{c}\text { Variables } \\
\text { Removed }\end{array}$ & Method \\
\hline 1 & EO, CREA $^{\text {b }}$ & & Enter \\
\hline
\end{tabular}

a. Dependent Variable: BP

b. All requested variables entered.

Table 6. Model Summary

Model Summary

\begin{tabular}{|l|c|r|r|r|}
\hline Model & $\mathrm{R}$ & R Square & \multicolumn{1}{|c|}{$\begin{array}{c}\text { Adjusted R } \\
\text { Square }\end{array}$} & $\begin{array}{c}\text { Std. Error of } \\
\text { the Estimate }\end{array}$ \\
\hline 1 &, $584^{\mathrm{a}}$ &, 341 &, 334 & 6,752607 \\
\hline
\end{tabular}

a. Predictors: (Constant), CREA, EO

Table 7. Anova

ANOVA $^{\mathrm{a}}$

\begin{tabular}{|ll|c|c|c|c|c|}
\hline Model & & Sum of Squares & $\mathrm{df}$ & Mean Square & $\mathrm{F}$ & Sig. \\
\hline 1 & Regression & 4638,912 & 2 & 2319,456 & 50,868 &, $000^{\mathrm{b}}$ \\
& Residual & 8982,747 & 197 & 45,598 & & \\
& Total & 13621,659 & 199 & & & \\
\hline
\end{tabular}

a. Dependent Variable: BP

b. Predictors: (Constant), CREA, EO

Table 8. Coefficients Coefficients $^{\mathbf{a}}$

\begin{tabular}{|c|c|c|c|c|c|c|}
\hline \multirow{2}{*}{\multicolumn{2}{|c|}{ Model }} & \multicolumn{2}{|c|}{ Unstandardized Coefficients } & $\begin{array}{c}\text { Standardized } \\
\text { Coefficients }\end{array}$ & \multirow[b]{2}{*}{$\mathrm{t}$} & \multirow[b]{2}{*}{ Sig. } \\
\hline & & $\mathrm{B}$ & Std. Error & Beta & & \\
\hline \multirow[t]{3}{*}{1} & (Constant) & $-1,858$ & 6,142 & &,- 303 & ,763 \\
\hline & EO & ,593 & 061 & ,583 & 9,674 & 000 \\
\hline & CREA & 004 & 085 & 003 & 048 & ,962 \\
\hline
\end{tabular}

a. Dependent Variable: BP

1. Table 5. "Variables Entered/Removed"shows the variables of personal creativity and entrepreneurial orientation variables as independent variables while business performance as the dependent variable.

2. Table 6. "model summary" displays a correlation value of 0.584 and interpreted that the relationship between the two research variables is in the medium category. In this table also obtained the value of R Square or coefficient of determination (CD) of 34.1\%. Thus it can be interpreted that the variables of personal creativity and entrepreneurial orientation have the effect of a contribution of $34.1 \%$ on the variables of business performance and the other $65.9 \%$ are influenced by other factors outside the variables of personal creativity and entrepreneurial orientation.

3. Table 7. "anova" is used to determine the significance level of regression. From the calculation results, the $\mathrm{F}$ number of the research is 50.868 and $\mathrm{p}$ count is 0.000 . Decision of the regression model is feasible and can be used to predict the business performance of the embroidery industry entrepreneur. This means that there is a linear relationship between personal creativity and entrepreneurial orientation with business performance.

4. Table 8. shows the relationship between personal creativity and entrepreneurial orientation to business performance. Based on the results of the calculation obtained: 
a) the number of research $t$ is 9.674 for entrepreneurial orientation with a significance value of 0.000 , which means there is a linear relationship between entrepreneurial orientation and business performance; and $b$ ) the number of research $t$ is 0.048 for personal creativity with a significance value of 0.962 , which means there is no linear relationship between personal creativity and business performance.

Because personal creativity variable does not have a relationship with the business performance variable, then trimming is done. Trimming results by issuing personal creativity variables, so that they are obtained as follows:

Table 9. Anova

ANOVA

\begin{tabular}{|ll|c|c|c|c|c|}
\hline Model & & Sum of Squares & $\mathrm{df}$ & Mean Square & $\mathrm{F}$ & Sig. \\
\hline 1 & Regression & 4638,806 & 1 & 4638,806 & 102,249 &, $000^{\mathrm{b}}$ \\
& Residual & 8982,853 & 198 & 45,368 & & \\
& Total & 13621,659 & 199 & & & \\
\hline
\end{tabular}

a. Dependent Variable: BP

b. Predictors: (Constant), EO

Table 10. Coefficients Coefficients $^{\mathrm{a}}$

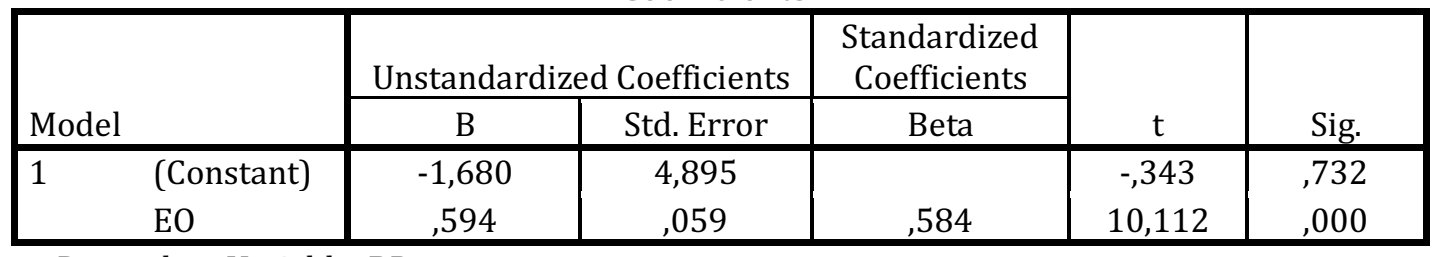

a. Dependent Variable: BP

1. Table 9. "anova" is used to determine the significance level of regression. From the calculation results, the F number of the research is 102.249 and $\mathrm{p}$ count is 0.000 . Decision of the regression model is feasible and can be used to predict the business performance of the embroidery industry entrepreneur. This means that there is a linear relationship between entrepreneurial orientation and business performance.

2. Table 10. shows the relationship between entrepreneurial orientation to business performance. Based on the results of the calculation obtained the number t research is 10.112 and $p$ count is 0.000 , which means there is a linear relationship between entrepreneurial orientation and business performance.

3. Thus, the model for the second path is:

or:

$$
Y_{2}=0,811+0,584 Y_{1}
$$

\section{Business Performance $=0,811+0,584$ Entrepreneurial Orientation}

\section{DISCUSSION}

Based on the results of the first path model, there is a direct effect of personal creativity variables on entrepreneurial orientation. This condition explains that the higher the personal creativity of an entrepreneur, the higher the entrepreneurial orientation. The results of this study support the research conducted by Lumpkin and Dess (1996) that entrepreneurial orientation refers to the willingness to support creativity and experimentation in introducing products/services and novelty, technological leadership and developing new process ideas. The results of the study by Daddie et al. (2017) concluded that creativity is the driver of entrepreneurship, namely creative individuals are more likely to lead to entrepreneurial 
orientation. Therefore Daddie et al. (2017) and Rahim et al. (2018) assert that there is a strong positive relationship between entrepreneurial orientation and individual creativity.

Personal creativity in generating new ideas requires initiatives to expand ideas into implementation or to be adopted as innovations. For this reason, the role of entrepreneurial orientation is needed so that ideas can be implemented properly by employees and can be accepted by customers. Entrepreneurial orientation is reflected in autonomy, innovation, willingness to take risks, proactive and aggressive competition. Autonomy which is the right of employers to make decisions and confidence to ensure the survival of their business supports entrepreneurs to be innovative, willing to take risks, proactive and aggressive.In addition, the willingness to take risks is where the employer is willing to make a commitment to the resources and at the risk he will face by implementing the new idea. While proactive refers to how entrepreneurs anticipate and act on the future needs of the market by looking for new opportunities that may or may not be related to new products. While aggressive competition refers to how entrepreneurs can outperform competitors and take advantage of these new opportunities.

The results of the study show that the variables of personal creativity do not have a direct influence on business performance. The results of this study do not support the results of research conducted by Sijabat (2017), Palilingan (2014), and Utama and Nadi (2017) that creativity directly influences performance. But the results of this study support the research conducted by Khedhaouria et.al (2014) which states that corporate creativity and performance are fully mediated by entrepreneurial orientation. Weinzimmer et al. (2011) also revealed that even though an organization has a certain level of creativity, this attribute does not affect performance directly.

The results of this study indicate that the relationship between personal creativity and business performance must be mediated by entrepreneurial orientation. So creativity is indirectly related to business performance through increased autonomy, innovation, risk taking, proactivity and aggressive competition. This shows that entrepreneurial orientation is a creative process in which entrepreneurs apply new ideas that lead to successful and highperformance innovations.

Khedhaouria et.al (2014) stated that creativity affects the performance of small businesses. Creative entrepreneurs encourage their business to achieve growth and success with the entrepreneurial process which leads to superior business performance. This is where entrepreneurial orientation can fulfill this role through its emphasis on autonomy, innovation, risk taking, proactivity and aggressive competition in pursuing new opportunities. The entrepreneurial orientation allows the development and exploitation of creative ideas for the growth of small businesses.

The results showed that entrepreneurial orientation variables had a significant positive effect on business performance variables as well as being an intervening variable that mediated personal creativity towards business performance. The results of this study support the research conducted by Valeria (2013) and Sofyan (2017) entrepreneurial orientation has a positive influence on business performance, which means that the higher the entrepreneurial orientation, the higher business performance.

Having an entrepreneurial oriented performance will make it easier for entrepreneurs to find ways to market their products or services better, run a business by producing products with different attributes than competitors. For that entrepreneurs must be able to recognize, and be 
able to determine exactly, what is the source of excellence, their innovation in competition. By continuing to maintain and develop sources of competitive advantage, the sustainability of the company will be maintained.

\section{CONCLUSION}

The results and discussion can be summarized as follows:

1. There is the influence of personal creativity on entrepreneurial orientation and there is an influence of entrepreneurial orientation on performance. But personal creativity does not have a direct influence on business performance. Thus entrepreneurial orientation is an intervening variable that mediates between personal creativity and business performance.

2. Suggestions that can be given to improve personal creativity of entrepreneurs are by participating in various trainings that can improve their ability to change their mindsets to be more creative and participate in various activities that can motivate themselves so they can be encouraged to do creativity.

\section{ACKNOWLEDGMENT}

This research project has been supported by postgraduate program of Universitas Sebelas Maret sponsored by Republic of Indonesia's Ministry of Research, Technology and High Education, and the Aceh Government.

\section{BIBLIOGRAPHY}

Amabile, T.M. 1998. How to Kill Creativity. Harvard Business Review. September-October 1998. 76-88 Amstrong, M. 2004. Performance Manegement. Yogyakarta: Tugu.

Daddie. J.A, Tambari. J.C, Nwigbo. T.S, 2017, The Nexus Between Entrepreneurship Orientation And Employees' Creativity In Selected Micro-Finance Banks In Portharcourt, Advance Research Journal of Multi-Disciplinary Discoveries, ISSN NO : 2456-1045, Volume : 12.0 / Chapter- XII / Issue -1 (April), p: 65-70

Glancey, K. 1998. Determinant of Growth and Profitability in Small Entrepreneurial Firms. Journal of Entrepreneurial Behaviour and Research.Vol. 4.No. 1. MCB University Press.

Jauch L.R. dan Glueck W.F. 1988. Business Policy and Strategic Management. New York: McGraw Hill.

Khedhaouria. A, Gurău. C, dan Torrès. 0, 2015, Creativity, Self-Efficacy, And Small-Firm Performance: The Mediating Role Of Entrepreneurial Orientation, Small Business Economics: An Entrepreneurship Journal, ISSN 0921-898X, Volume 44, Number 3, p: 485-504

Lumpkin, G.T., \& Dess, G.G. 1996. Clarifying the Entrepreneurial Orientation Construct and Linking It To Performance. Academy of Management Review, Vol.2, No.1, p 135-172.

Messaghem K. 2003. Strategis Entrepreneurship and Managerial Activities in SMEs. International Small Business Journal.Vol. 21 No. 2. 197-212

Miller, D. 1983. The Correlates of Entrepreneurship in Three Types of Firms. Management Science. Vol. 29, 770-791.

Okpara, F.0. 2000. Entrepreneurship: Text and Cases. Enugu: Precision Printers and Publishers.

Palilingan. V.R. 2014. Pengaruh Kreativitas, Entrepreneurship dan Kecerdasan Kompetitif terhadap Kinerja Pimpinan Program Studi, Invotec, Volume X, No.2, Agustus 2014, p: 153-168

Rahim. A.W.P.A, Wan Ismail. W.K, Thurasamy. R, Rahman. I.A, The Relationship of Individual Creativity with Entrepreneurial Intention via Individual Entrepreneurial Orientation (IEO), International Journal of Innovation and Business Strategy (IJIBS)/ Vol. 9, No. 1, January 2018, p: 41-54

Robbins, S.P. dan Judge, T.A. 2008. PerilakuOrganisasi 1. Edisi 12. Jakarta: Salemba Empat.

Sijabat. R, 2017, Penguatan Kinerja Pemasaran Melalui Pengembangan Inovasi dan Kreativitas Program Kerja Pada Wirausaha Muda di Semarang, Jurnal Sains Pemasaran Indonesia, Volume XVI, No. 1, Mei 2017, p: 26-43 
Sofyan, 2017, Orientasi Kewirausahaan, Kinerja Inovasi dan Kinerja Pemasaran Usaha Mikro, Kecil dan Menengah pada Sentra Industri Tas desa Kadugenep, Jurnal Riset Bisnis dan Manajemen Tirtayasa, ISSN (Online) 25990837, Vol. 1 (1), p: 65-79

Suryana. 2013. Ekonomi Kreatif. EkonomiBaru: Mengubah Ide dan Menciptakan Peluang. Jakarta: Salemba Empat.

Utama. L, dan Nadi J.K, 2017, Pengaruh Kreativitas Terhadap Kinerja Usaha dengan Orientasi Kewirausahaan Sebagai Mediasi pada Wirausaha di ITC Cempaka Mas, Conference on Management and Behavioral Studies Universitas Tarumanagara, Jakarta, 12 Oktober 2017, ISSN NO: 2541-3406 e-ISSN NO: 2541-285X, p: 80-88

Valeria. N.P, 2013, Membangun Kinerja Bisnis Melalui Keunggulan Bersaing pada UKM Manufaktur (Studi Empirik Pada Industri Logam di Kecamatan Ceper, Kabupaten Klaten), Jurnal Bisnis Strategi Vol. 22 No. 1 Juli 2013, p: 133142

Weinzimmer. L.G, Michel. EJ, dan Franczak. JL, 2011, Creativity and Firm-Level Performance: The Mediating Effects of Action Orientation, Journal of Managerial Issues, Vol. 23, No. 1 (Spring 2011), p: $62-82$

Wiklun, J. 1999. The Sustainability of the Entrepreneurial Orientation Performance Relationship. Entrepreneurship: Theory and Practice. Vol.24. No.1.p 43-53

Wiklund, J. dan Shepherd, D. 2003. Knowledge-base Resources, Entrepreneurial Orientation, and the Performance of Small and Medium Sized Business. Startegic Management Journal.Vol. 24.p 1307-1314.

Zahra, S.A. 1993. A Conceptual Model of Entrepreneurship as Firm Behaviour: A Critique and Extention. Entrepreneurship Theory and Practice.Vol. 14. No.4. p 5-22.

Zahra, S.A. dan Neubaum, D.N. 1998. Environmental Adversity and the Entrepreneurial Activities of New Ventures. Entrepreneurship Theory and Practice, Vol. 3. p 123-140.

Zimmerer, T.W. dan Scarborough N.M. 2005. Pengantar Kewirausahaan dan Manajemen Bisnis Kecil, Edisi Keempat. Jakarta: PT. Penebar`Swadaya. 